\title{
National Identity in Traditional Ideological Discourse of the Islamic Revolution
}

\author{
Hamid Sarmadi ${ }^{1, *}$ \\ ${ }^{1}$ Political Science in Research Branch Islamic Azad University, Tehran, Iran \\ *Correspondence: Political Science in Research Branch Islamic Azad University, Tehran, Iran. E-mail: \\ hamedsarmadi2000@yahoo.com
}

Received: July 16, 2016

Accepted: August 5, 2016 Online Published: January 25, 2016

doi:10.5430/sass.v4n1p15

URL: http://dx.doi.org/10.5430/sass.v4n1p15

\begin{abstract}
The traditional ideological discourse of the Islamic revolution was formed by the safeguard and support of the past achievements and also to preserve the historical heritage. It was one of the rings attached to the compatibility of the religious and national identity in contrast of the Pahlavi's extremism that emphasized the leasing of Shiite's elements, the identity of Western modernity and tyranny.

Following of this hegemonic discourse after the Islamic revolution. We can see the adoption of religious and national values. It is strengthened the national identity by the central slab of religious democracy and some elements such as ; civil society, rule of law, development of higher education, political participation, economic development, civil rights and human dignity.
\end{abstract}

Keywords: traditional ideological discourse, discourse analysis, national identity, Ernesto Laclau, Chantal Moufe

\section{Introduction}

Islamic Revolution in Iran and the consequences of that in terms of cultural, political and social issues affected the national identity and Iranian identity and its dimensions become important. This discussion was the sign of the extreme otherness of the ancient Iranian nationalism which was trying to make the Iranian values as its own legitimacy of foundation, while it was weakening of the national identity. After the second decade of the formation and establishment of the Islamic Revolution, it was helped the strength of national identity with the focus on religious democracy, an emphasis on cultural characteristics, historical records and focusing on elements such as; efforts of political participation, the expansion of higher education, a positive attitude to the concept of civil rights, preservation Islamic and national values. Of course it depends on the coincidence of the changes and needs of modern society. The purpose of this study is probing and analyzing the characteristics and epistemic of the traditional ideological discourse of the Islamic revolution and the articulation of the elements of national identity during the years 1978 to 2005. The techniques of this study will be the Laclau and Mouffe's discourse.

After the Islamic Revolution the national identity was posed in a relation of the Islamic identity. This relationship Islamic Revolution was intended with the traditionalist ideological discourse and with the central slab of political Islam in the first decade, and in the second and third decades with the central slab of the religious democracy caused the strength of the national identity in Islamic Revolution discourse. This has inevitably affected the political norms. And from this moment on, the views and attitudes of the political system was deeply and comprehensively changed. In this paper, the basic question is the place of national identity in the traditional ideological discourse of the Islamic revolution? The hypothesis; the traditional ideological discourse of the Islamic revolution in the first decade with the central slab of political Islam and some elements such as; revival of Islamic identity, Islamic jurisprudential and noticing to Umm al-Qura of the Islam for showing the Muslim community as its main goal and it had the minimum noticed on the components of the national identity. But the second decade with the central slab of construction and elements such as; economic development, the expansion of the middle class, will mean the expansion of higher education, and the third decade was strengthen the national identity with the central slab of religious democracy and considering elements such as; civil society, increase political participation, civil rights. 


\section{Literature Review}

According to previous studies, among the scientists from different fields different views have been expressed on the origin, evolution of nation, nationality and national identity, which are divided in two main schools of archaism (eternal ideas,) and modernists (tool Islamists). According to the first group, nationality and ethnicity primary and fundamental nature of human life. And the second group, believe that it is a product of the modern era and economic- political developments contemporary of human life and social evolution as a result of Western modernity is worthy of attention. This study is based on the first approach. Because national identity like other categories is not instantaneous and immediate and it needs some steps for forming.Traditionally, scholars disagree lead to different perceptions of the concept of national identity in Iran. In the constitution era the national identity in the context was changing of a vassal to citizens and the formation of a civil society. Whereas in the Pahlavi era, the meaning of national identity, was considered as the official ideology Pahlavi monarchy. Another meaning of national identity was raised by leftist groups in many years later, that used Iran's peoples instead of people, they said that Iran is a multinational country, they emphasis oneself-determination of peoples by raising the issue of national. We can see other treatment of national identity in the works of Bazargan, Ayatollah Taleghani and Ayatollah Motahari, who saw the national identity in the integration of religious identity and knew the two inseparable.

\section{Methodology}

In this study, we are going to use the discourse analysis, to examine the position of national identity of the Islamic Revolution discourse. Ernesto Laclau and Chantal Mouffe, are believed on the understandability of the social meaning of words, statements, acts and structures, in relation to the general area that they are part of it with emphasis on communication and identity discourse(Jorgensen\&Philips, 2002:78). In other words, discourse analysis pays special attention to the challenges and discourse competition on the definition of the phenomenon and identity. All have different meanings and identities that a word has taken on a certain type of discourse depends on who gives it meaning and existence (Wodak, 2008:247). Laclau and Mouffe know the discourse as a whole meaningful that gives transcendence the distinction between language and meta-languages. According to this, they believe that the whole package in which the link between signifier and signified became alike, is also impossible. In this respect, there is a kind of proliferation of floating slab in society, and the political competition are in a specific configuration as an effort of political forces to stabilize the relative signifiers (Tajik, 2000: 93). Hegemony of a discourse is based on semantic integrity of the central signifier (Laclau \& Moffe, 2001: 153).

\section{Finding}

On the political side, national identity is based on regular and significant similarity between a group of people who name people, that living within a territory and national governments to implement common sense to them (Kaiseri, 1992: 153). Patrik believes that national identity has three parts as follows: First, the common foundation of political community that includes laws and norms that are agreed, second, an image of a nation that is shared among the members of the national community, and third, a sense of loyalty and personal commitment to the political community. He defines the national identity as "personal understanding of which reflects the qualities of a nation on their own, the good qualities they have and want to have it". Therefore, people are always trying to comply with this perception and behavior, and if they fail to do so, they are depressed and guilt (Patrik, 2000: 42).

\subsection{Components of National Identity (Country, History, Religion, Language)}

Four components of national identity in Iran indicate the formation of national identity in the long term; 1.Country 2. History 3. Religion 4. Language

\section{A. Country}

Undoubtedly, the identity of a nation is primarily a geopolitical issue and it is concerned to determine how the survival of the nation. A country, when is alive and independent that at the beginning of each has an independent national character and a new character of national identity of a community become existence whenever there is its combined statements (Mojtahedzade, 1999: 47-45). The country; is realization of independence of government and freedom of political power and gives the legal authority to political elite that be able to continue to reign and rule of collective life of citizens under discipline within the territorial limits without interference from others. Freedom and national independence requires that each person have a specific country and finally, the country given to the nation visualization and object, leading to the survival of national sovereignty (Tabatabai Motameni, 2001: 33-31). 


\section{B. History}

Historical dimension of national identity includes; awareness of society's members to the past history and attachment to it. The sense of though the fate binds the various generations of a nation(Goudarzi, 1999: 28).This definition encompasses three dimensions:

1.Historical knowledge, as a knowledge of the most important events and historical figures

2.historical attachment, implies the existence of positive and negative emotions against the events, positive and negative events and characters that leads to positive and honorable behavior with it or being successful in activities of effective and positive figures in its history or it is the sense of pride or discomfort and embarrassment and humiliation.

3.Historical efforts are meant the degree of importance of history in comparison with other important items (Memar, 1999: 56). The history of Iran is one of the main elements of Iranian national identity, which represents the early development of community spirit and long periods of Iranian national identity. Of course, it is important to note that Iran is primarily composed of two main parts: mythical and historical monuments; and these two parts has been shown as well as in the historical acts (Ahmadi, 2003: 50). However, the history of Iran is forming the attitude and sometimes the Iranians character and also it is an important basic for understanding of Iranians themselves and introduce themselves to others and in other words is their identity.

\section{Religion}

Having a common religion and religious teachings, commitment and loyalty to the faith and rites and rituals tend to spread are very effective in the process of shaping national identity. Today, religion is an important part of the process of collective identity and is the national identity of the people(Goudarzi, ibid: 30).

Traditionally, religion has had an important place in political and public life of Iranian. Until the arrival of Islam in Iran, Zoroastrianism, was the dominant religion of the people (Shaygan, 2004: 162).After the arrival of Islam in Iran, the majority of people was converted to this religion and after the establishment of the Safavid Shiism was formalized in this country.

By the arrival of Islam in Iran, we can see the formation of a mixed identity Iranian -Islamic that other elements would be added in later periods (Jafarian, 2002: 12).During this period, the pre-Islamic Iranian mythical ideas of time and space, combined with Islamic beliefs, Iranian intellectuals in the early years of Islam in Iran played the largest role in the creation of culture, civilization and Islamic identity, so the ways of thinking the culture was watered, and effected on it(Nazari and Sazmand, 2008: 187).

\section{Language}

Language is an important aspect of the heritage of any nation. Language is not only as a social product, a tool and means of communication, but as part of social relationships that produce and reproduce culture and identity and has an important role for any society (Hajiani, 1999: 206).In Iran, the Persian language by all the changes during the history of fusing with Turkish Mongolian and Arabic, was on the side of Islam in the Safavid era and gave a new personal to Muslim Iran and distinct and determined the Iranian Muslim from the majority of other Muslims.

\subsection{The Traditional Ideological Discourse of the Islamic Revolution}

The traditional ideological discourse was developed in the late Pahlavi's era and after the Islamic Revolution in 1987, was overcome in the context of the political system, which is composed of elements of the "patrimonial" and "Shiite political theory".

This discourse are formed with the central slab of political Islam and with the elements such as,anti-liberalism and the traditional enlightenment and emphasis on mass mobilization and elitism and leadership, obedience, discipline and solidarity on the basis of religious identity, such as: law, governmental economy, spiritualists, political authoritarianism, idealism, the export of the Islamic Revolution of binary oppositions between Islam and blasphemy. The mentioned discourse emerged in response to the collapse of traditional solidarity discourse and mass society in the Pahlavi era and was subsequently lost to the security of the traditional world of mass mobilization and supply of pervasive ideology compensate (Bashiriyeh, 2008 65). This discourse is intended to provide a new approach to "national identity" and concepts such as the identity of the vacuum gap and compensation soulless capitalism. This discourse had an important role along two rival discourses, socialism in Iran. Between years 20 to 57 was introduced as an important intellectual current political, social and ideological religion was revived and wanted to establish of a political system based on Islamic values and the Islamic regime in Iran to provide their views payment (Fawzi, 2009: 63).The traditional ideological discourse of the Islamic revolution was formed in the first decade of the Islamic 
Revolution as a political discourse based on the ideas of Imam Khomeini Islamic jurisprudential Fqahty. During this historical period in the power block level, a social and apolitical and non-ideological religion essentially was introduced meaningless and "religion" were raised with the ideological approach and commitment and belief on "velayat-e faqih" was important as two sides of a coin and was emphasized on a state-run economy (Islamic socialist)(Tajik, previous: 189).

\subsection{The Place of National Identity in the Traditional Ideological Discourse of the Islamic Revolution}

A: The first decade (1978-1989 traditional ideological discourse)

In the period after the revolution because of the rule, was emphasized only on certain aspects of the national culture, the religious aspect. In order to explain and identify the elements of national identity, it is necessary to notice to the eight-year war and the nature of the revolution. These terms and features, along with the embassy of America, along with the embassy of America, the fall of the interim government, started disputes and division of the People's Mojahedin, escaped of the first President and then assassination of the second President and also the atmosphere of terror and civil strife and led to the threat of suspension of government reform and revolution in terms of decision-making was very difficult (Shahbazi, 2001: 234). At this point, characters and words of Imam Khomeini as Iran's driven by government policies and practices in the organization of the society, culture, politics and the political approach to national identity and geography is largely a reflection of their opinions (Bashiriyeh 1997: 94-93).

In the first decade, the rituals and religious rites were tremendous importance for the most minor change of cultural-values aspects and symbols of national identity that was emphasized by Pahlavi regime, it was desperate attempted from naming streets to naming babies (Zuhairi , ibid: 169). Also, national identity was based on the change in the perception of social issues and return to Islamic solution. Reaching to this goal, was possible only through an emphasis on cultural and ethical advertising, education, clean up the community of Western values, underestimate the importance of strengthening the economic and spiritual values (Najmabadi, 1998: 163). So in the first decade of a collective agreement, the religious approach became so deep that national identity became equal of religious identity and other aspects of identity, were considered as a low-cost components.

B: The second decade (1989-1997 constructive dialogue)

After a difficult and stressful transition from the first decade of the revolution, was begun by the second period of the central slab of (nodal point) the constructive dialogue. During this period, the political and economic structure of the country were changed by the internal and external requirements, such as the economic turmoil caused by the war and the need for capital and foreign technology and changes in international behavior and acceptance of international order. Thus, a new era of conflict between tradition and modernization began in the Islamic Republic of Iran. The problems posed by these challenges, led to coexist of the intellectual elite and a means to monitor the Iranian element of national identity and religious identity. So with an emphasis on Iranian traditions as part of the national identity conducted to reconcile these traditions with religious values. This process could lead to strengthen the capacity of building national identity. In the second decade of the revolution, we are seeing the trend of traditional authority instead of the first decade of charismatic authority, paving the way for the gradual organization of the new middle class and intellectuals, opening Universities, multiple elections and public participation, tending to weaken some elements of the oligarchy and mass mobilization, the adoption of capitalist tendencies, private economic, of the things (Bashiriyeh, ex: 1999). These elements provided of public participation in the 1376 elections. Hence the need for the involvement of organized civil society was a clear necessity to strengthen the concept of national identity in the democratic and religious democracy (Hashemi Charsoqheh, 2012: 71).

Community Economic Development and Reconstruction (1989 to 1999) with the articulation of signifiers such as; economic reform and expansion of higher education, could advance the traditional ideological discourse of the Islamic Revolution to religious democracy.

C: The third decade (discourse of religious democracy 1997-2005)

After the Islamic Revolution various challenges occurred between the different strands about the reform model, which in the socio - political area the most important challenge was about the political system in the country or the relationship between Islam and democracy. The mechanism of integration of Islam and republicanism and debating of political and social freedom and discussing the issue of equity of nations and equality of minorities with Muslims and equality of women and men were other controversial issue between the various factions in the political sphere social. Imam Khomeini as a jurist and political ideologists and his jurist followers made an established- combination model of post-revolutionary modernization and drafted it in the framework of new constitution, which based on that the modernization pattern after the revolution had unique dimensions of establishment with its own characteristics, 
but at the same time, it had the ability to obtain the rational elements of new civilization, too. This pattern in the political sphere supported of the incorporation of the Republic (as a modern thought) and Islamic and it is trying in the cultural areas with new tools for the development and promotion of education, arts, sports and cultural needs of contemporary societies and finally helps to strengthen national identity. Idea and theory of religious democracy in the third decade were affected by the ideas of Imam Khomeini that presented by Ayatollah Khamenei and Hojjatoleslam Khatami in the '1991s. In this decade, increasing the participation and interpretation of the potential implications of the constitution as freedom, participation, accountability, rights of nations and others demonstrated the degree of the strengthening of governments and the relation of people with the political system. The action of Imam and his followers is important in the sense that will gather the religious considerations of government with general willing (Eftekhari, 2007: 54) This approach reinforces the concept of the people, the rights of citizens, the participation of ethnic families, respect for the rights of women and ultimately national identity. Thus, the consensus between republicanism and Islamism and strengthen the process of consensus between the two different approaches of republicanism and Islamism are the main purpose of national identity in the concept and discourse of religious democracy. And national identity had a special reference and a special discourse for their continuing and reliability and dynamics at any time, is not always possible, to draw the different levels of community for the pillars of national identity for example in the form of the traditional ideological discourse and the symbols associated with it, and was given an ideological approach to Iranian political theory and practice.

\section{Conclusion}

Either we cannot ignore the role oftens of centuries before the Islamic civilization in the formation of the Iranian identity, or denying the role of Islam during the fourteen century for making the today's Iran. Islam has a profound effect on Iranian culture and identity and it also has great interest the Iranian civilization and culture. We found with one glance at the evolution of the socio - political in the first decade of the Islamic Revolution, that statements tradition ideological discourse of the Islamic Revolution which the statements of traditional ideological discourse of the Islamic Revolution accountability and efficiency in all dimension of social life has not been successful and, therefore, the inadequacy of the traditional and ideological interpretation of Islamic relation to how to deal with the demands of the modern world and the challenges of national identity, Iranian society had found guidance to the new discourse and to Companion as signifiers of republican and Islamic religious democracy. In the second and third decades, while strengthening the Islamic element of national identity and citizenship, partly emphasized on the underlying components were Iranian. In this new approach, national identity are basically coincidence with the pillars of religious identity and Islamic values and being Islamic and being Iranian mixed together so it was impossible to distinguish from each other. At this point, with some elements such as political participation, civil society, rule of law and the subsequent recognition of the arts, entertainment, sports, youth and women's rights and religious and civil rights standards the people feel that they can take part and influence in the fate of individual identity.

Also from the perspective of the relationship between national identity and religious democracy, is strengthen the national identity by the need for preservation of evidence republican political system means participation of the people to participate and exert influence in political and economic fields, noticing to civil rights, women's rights, ethnic and linguistic minorities in accordance with the constitution of the Islamic Republic of Iran, discussing with representatives of different ethnic and cultural intellectual and acceptance of universal values with national conditions, combined with adhering to the idea of democracy and peace with the idea of velayat-e faqih, alternative religious democracy rather than Western liberal democracy, respect interpretative and critical aspects of modernity that its symbols in politics, including democracy, human rights and civil society, and finally took the important thing, not necessarily caused by the change in the discourses of Islamic Revolution of Iran's new status.

\section{References}

Ahmadi, H. (2003). Iranian national identity in the context of history. The National Studies, 15, 47-9.

Bashiriyeh, H. (1997). Civil society, power, ideology barriers to the realization of civil society in Iran", from the book: the realization of civil society in the Islamic Revolution of Iran (Proceedings). Tehran, Islamic Revolution Cultural Documentation Organization.

Bashiriyeh, H. (1999). The political development in Iran after the revolution. Tehran, Negah-e-Moaser.

Charsoqh Hashemi, M. (2012). Political development in Iran after the revolution, according to the discourse at 
religious democracy. Political outcome, autumn and winter, 10- 37 and 38.

Eftekhari, A. (2007). The national interests of the Islamic Republic of Iran. Tehran: Center for Strategic Studies.

Fawzi, Yahya. (2009). The socio-political developments in post-revolutionary Iran, Tehran: Fawzi, John (2009), the socio-political developments in post-revolutionary. Iran, Tehran: Publication of Oroj.

Goudarzi, M. (1999). Cultural developments in Iran. Tehran: Publication of Ravesh.

Hajiani, E. (2000). Sociological analysis of national identity in Iran and a few assumptions. The National Studies, 5, 228-193.

Jafarian R. (2002). A component of national identity in the midst of the four-century developments in Iran. Tehran: Publication of cultural studies and humanities.

Kaisari, N. (1992). Arab ethnicity and national identity in Iran. Journal of Strategic Studies, 1, 49-83.

Laclau, Ernesto \& Moufe, Chantal. (2001). Hegemony \&Strategy. London.

M.W Jorgensen \&M Philips. (2002). Discourse Analysis as theory and method. London: sage publication.

Memar, R. (1999). To assess trends in the historical identity of Iran. Tehran, IRIB Research Center and program evaluation.

Mojtahedzadeh, Piruz. (2000). The idea of geopolitics and reality in Iran. Tehran: Publication of Ney.

Najafi, Mosa. (2005). Spiritual aspect of national identity in Iran. Tehran: Publication of Maref.

Najmabadi, Afsaneh (1998). Return to Islam, from modernism to the moral order. translation Abbas Keshavarz Shokri Journal Matin, the first year, winter.

Nazari, Ali Ashraf, Bahareh Sazmand. (2008). Discourse, identity and the Islamic Revolution. Tehran, Islamic Revolution Documents Center.

Patrik, Morag. (2000). Identity and the Politics of Recognation: in noel'sullivan political theory in transition. London: Routledg.

Shahbazi, Mahbob. (2001-2000). The democracy of the political system of the Islamic Republic of Iran (comparative analysis of the presidential election)," Master's thesis in political science, Imam Sadiq University, the first academic semester 80-2000 .

Tabatabai Motameni, M. (2001). Fundamental rights, Tehran Fawzi, John (1388), the socio-political developments in post-revolutionary. Iran, Tehran: Publication of Mizan.

Tajik, Mohammad Reza. (2004). Narrative identity and otherness among Iranians. Tehran: a culture of discourse.

Wodak, Ruth. (2008). The contribution of critical linguistics to the analysis of discriminatory prejudices and stereotypes in the language of politics. NewYork. https://doi.org/10.1515/9783110198980.3.291

Zuhairi Ali Reza. (2010). Islamic Revolution and national identity. Qom, Iran's Islamic community. 